\title{
Kultur Bifasik Agar Gold Standard Deteksi Kuman Mycobacterium Tuberculosis pada Pekerja Tambang Emas Tradisional (Studi di Lebong Tambang Bengkulu)
}

\author{
Darmawansyah $^{1}$, Wulandari ${ }^{2}$ \\ 1,2Program Studi Kesehatan Masyarakat, Universitas Dehasen Bengkulu \\ Jl. Meranti Raya No.32, Sawah Lebar, Ratu Agung, Bengkulu, 38222 \\ Email: ${ }^{1}$ darmawansyah@unived.ac.id, ${ }^{2}$ wulandarisanny@gmail.com
}

\begin{abstract}
Abstrak
TB paru merupakan penyakit paru akibat infeksi kuman Mycobacterium tuberculosis, yang menyebabkan kematian hampir disebagian besar negara di seluruh dunia. Case Notification Rate BTA positif baru dan semua kasus dari tahun ke tahun di Indonesia mengalami peningkatan. Angka Kematian TB Paru di Provinsi Bengkulu sebesar 35 kasus selama pengobatan. Di Kabupaten Lebong kasus TB Paru terjadi peningkatan pada pekerja tambang emas tradisional dari $32 \%$ kasus meningkat menjadi $37 \%$ kasus. Di Kabupaten Lebong belum pernah dilakukan deteksi dini kuman Mycobacterium tuberculosis pada pekerja tambang emas tradisional, dimana kasus TB Paru di Kabupaten Lebong masih tinggi, maka perlu dilakukan deteksi kuman Mycobacterium tuberculosis untuk pemberatasan penyakit TB Paru dengan menggunakan metode kultur bifasik agar. Tujuan penelitian adalah untuk mengetahui adanya kuman Mycobacterium tuberculosis pada media kultur bifasik agar pada sputum pekerja tambang emas tradisional. Penelitian ini mengunakan pre experimental study untuk melakukan identifikasi kuman Mycobacterium tuberculosis dalam sputum dengan metode kultur bifasik agar. Sampel penelitian sebanyak 270 responden dengan kriteria inklusi sebagai penambang emas tradisional di Lebong tambang. Analisis yang digunakan adalah analisis distribusi frekuensi dan persentase variabel penelitian. Hasil penelitian didapatkan 270 sputum yang diperiksa menunjukan $49(18,1 \%)$ responden yang positif teridentifikasi kuman mycobacterium, 99 (36,7\%) responden berpendidikan SMP, dan $176(65,2 \%)$ responden memiliki umur produktif. Diharapkan kepada instansi kesehatan melaksanakan deteksi dini TB Paru pada pekerja tambang emas tradisional secara rutin, selain itu melaksanakan upaya preventif, promotif, dan kuratif untuk eliminasi TB Paru.
\end{abstract}

Kata kunci : TB Paru, Kultur Bifasik Agar, Pekerja tambang emas tradisional.

\begin{abstract}
Pulmonary tuberculosis is a lung disease caused by Mycobacterium tuberculosis, which causes death in almost all countries around the world. Case Notification Rate of BTA is positively new and all the cases from year to year in Indonesia have increased. The mortality rate for pulmonary TB in Bengkulu Province was 35 cases during treatment. In Lebong Regency, there is an increase in pulmonary TB cases in traditional gold mining workers, from $32 \%$ of cases to $37 \%$. In Lebong Regency, the detection of Mycobacterium tuberculosis for traditional gold mining workers has never been carried out, while the case of pulmonary TB in Lebong Regency is still high, it is necessary to detect Mycobacterium tuberculosis bacteria to eradicate pulmonary TB disease by using Agar Biphasic Culture method. The aim of this study is to determine the presence of Mycobacterium tuberculosis bacteria in agar biphasic media for traditional gold miners. This study used an pre experimental study to identify the Mycobacterium tuberculosis bacteria in sputum with agar biphasic culture methods. The research sample was 270 respondents with inclusion criteria as traditional gold miners at Lebong Tambang. The analysis used is the analysis of frequency distribution and percentage of research variables. The results showed that 49 (I8.1\%) respondents from 270 sputum examined were positively identified with mycobacterium bacteria, 99 (36.7\%) respondents had junior high school education, and 176 (65.2\%) respondents had productive age. It is expected that health agencies to carry out early detection of pulmonary TB in traditional gold mining workers on a regular basis, in addition to implementing preventive, promotive and curative efforts to eliminate pulmonary TB.
\end{abstract}

Keywords : Pulmonary TB, Agar Biphasic Culture, Traditional Gold Mining Workers. 


\section{Pendahuluan}

Tuberkulosis paru adalah penyakit paru akibat infeksi kuman Mycobacterium tuberculosis. Penyakit ini merupakan penyebab utama kecacatan dan kematian hampir disebagian besar negara di seluruh dunia. ${ }^{1,2}$

World Health Organization (WHO) menyatakan bahwa tahun 2015 kasus TB Paru sebanyak 6,1 juta dan tahun 2017 sebesar 10 juta dimana kasus kematian akibat TB Paru sebesar 1.6 kasus. Angka notifikasi kasus Basil Tahan Asam (BTA) positif baru dan semua kasus dari tahun ke tahun di Indonesia mengalami peningkatan. Angka notifikasi kasus pada tahun 2015 untuk semua kasus sebesar 130 per 100.000 penduduk, tahun 2016 sebesar 139 per 100.000 penduduk, dan tahun 2017 161 per 100.000 penduduk. $^{3,4}$

Data Dinas Kesehatan Provinsi Bengkulu tercatat jumlah kasus TB Paru mengalami peningkatan dari 1.423 kasus menjadi 1.951 kasus serta angka kematian TB Paru selama pengobatan sebesar 35 kasus. Data Dinas Kesehatan Kabupaten Lebong kasus TB Paru terjadi peningkatan pada pekerja tambang emas tradisional yaitu 32\% (44 kasus) menjadi 37\% (51 kasus). ${ }^{5}$

Lebong Tambang memiliki pertambangan emas tradisional, sebagian besar masyarakatnya mempunyai mata pencarian sebagai penambang emas tradisional. Pertambangan emas di Desa Lebong Tambang terletak di daerah pegunungan yang aktivitasnya sering dilakukan malam hari, kondisi yang dingin membuat pekerja tambang sering melakukan kebiasaan merokok. Kebiasaan merokok akan merusak pertahanan tubuh paru yang disebut "Muccucilliary Clearance" dimana bulu-bulu getar dan bahan lain di paru tidak mudah untuk membuang infeksi yang sudah masuk sehingga berisiko untuk terjangkit TB Paru. Kondisi Lingkungan kerja dipertambangan emas tradisional yang dilakukan di dalam lubang bawah tanah yang kurang mendapatkan pencahayaan sinar matahari membuat kuman Mycobacterium tuberculosis akan berkembangbiak dengan baik sehingga berisiko untuk penambang emas tradisional yang melakukan kegiatan pengeboran batu tambang. ${ }^{6,7,8}$

Di Kabupaten Lebong belum pernah dilakukan deteksi dini kuman Mycobacterium tuberculosis pada pekerja tambang emas tradisional, dimana kasus TB Paru di Kabupaten Lebong masih tinggi, maka perlu dilakukan deteksi kuman Mycobacterium tuberculosis untuk pemberatasan penyakit TB Paru dengan menggunakan metode kultur bifasik agar. Tujuan penelitian adalah untuk mengetahui adanya kuman Mycobacterium tuberculosis pada media bifasik agar pada sputum pekerja tambang emas tradisional.

\section{Metode}

Jenis penelitian yang digunakan dalam penelitian adalah pre experimental study dengan rancangan one shot case study yaitu melakukan identifikasi kuman Mycobacterium tuberculosis dalam sputum dengan metode kultur bifasik agar pada pekerja tambang emas tradisional di Desa Lebong Tambang Kabupaten Lebong.

Populasi pada penelitian ini sebanyak 270 responden, dimana teknik pengambilan sampel adalah total sampling yaitu semua populasi dijadikan sampel dengan memenuhi kriteria inklusi memiliki pekerjaan sebagai penambang emas tradisional di Lebong tambang.

Pengumpulan data dilakukan dengan cara pengambilan sputum pada pekerja tambang emas tradisional. Sputum yang diambil dimasukkan ke dalam tabung steril dicampurkan dengan larutan $\mathrm{NaOH} 4-8 \%$. Sputum di campur dan diaduk selama 1 menit kemudian diambil dengan ose steril dan dipulaskan di atas permukaan tabung medium. Masing-masing tabung media pembenihan di tutup dan tabung tersebut dieram dalam incubator dengan suhu $37^{\circ} \mathrm{C}$. Hasil di baca setiap hari, jika ditemukan koloni maka kulutr dinyatakan positif. Analisis dalam penelitian ini menggunakan 
analisis distribusi dan persentase variabel penelitian yaitu ditemukan kuman Mycobacterium tuberculosis pada sputum dan tidak ditemukan kuman Mycobacterium tuberculosis pada sputum. Proses analisis dilakukan menggunakan statistik deskriptif dengan membuat tabel distribusi variabel yang diukur.

\section{Hasil}

Tabel 1. Hasil Pemeriksaan TB Paru pada Pekerja Tambang Emas Tradisional

\begin{tabular}{lcc}
\hline \multicolumn{1}{c}{ Hasil Pemeriksaan } & n & \% \\
\hline Tidak teridentifikasi & 221 & 81,9 \\
$\begin{array}{l}\text { Kuman TB Paru } \\
\text { Teridentifikasi }\end{array}$ & 49 & 18,1 \\
Kuman TB Paru & & \\
\hline
\end{tabular}

Tabel 2. Distribusi Frekuensi Pendidikan Pekerja Tambang Emas Tradisional

\begin{tabular}{lcc}
\hline \multicolumn{1}{c}{ Pendidikan } & $\mathrm{n}$ & $\%$ \\
\hline SMA/SMK & 65 & 24,1 \\
SMP/MTsN & 99 & 36,7 \\
SD & 90 & 33,3 \\
Tidak Sekolah & 16 & 5,9 \\
\hline
\end{tabular}

Tabel 3. Distribusi Frekuensi Umur Pekerja Tambang Emas Tradisional

\begin{tabular}{|c|c|c|}
\hline Umur & n & $\%$ \\
\hline $15-50$ & 176 & 65,2 \\
\hline$>50$ & 94 & 34,8 \\
\hline Mean & \multicolumn{2}{|c|}{43,2} \\
\hline Median & \multicolumn{2}{|c|}{45,0} \\
\hline Maksimum & \multicolumn{2}{|c|}{18} \\
\hline Minimum & \multicolumn{2}{|c|}{67} \\
\hline
\end{tabular}

Berdasarkan tabel 1. diketahui dari 270 responden, $49(18,1 \%)$ responden teridentifikasi Kuman TB Paru. Dari 270 responden, $99 \quad(36,7 \%)$ responden berpendidikan SMP/MTsN dan 19 (5,9\%) responden tidak sekolah. Sedangkan dari 270 responden, $176(65,2 \%)$ responden memiliki umur 15-50 tahun. Rata-rata responden berumur 43,2 tahun, dimana responden paling mudah berumur 18 tahun dan paling tua berumur 67 tahun.

\section{Pembahasan Hasil Pemeriksaan TB Paru}

Hasil penelitian diketahui dari 270 responden, $49 \quad(18,1 \%)$ responden teridentifikasi kuman Mycobacterium tuberculosis dalam sputum dengan menggunakan metode kultur bifasik agar.

Deteksi sputum dengan metode kultur bifasik agar untuk mengetahui adanya kuman Mycobacterium tuberculosis dengan melihat ciri-ciri koloni dan sifat pertembuhan bakteri. Pertumbuhan kuman Mycobacterium tuberculosis terlihat dalam waktu 2 minggu dan memiliki karaktersitik berwarna kuning pucat dengan permukaan koloni tampak kering, rapuh, dan tidak rata.

Menurut Purwaningsih, bahwa bakteri Mycobacterium tuberculosis apabila dibiakan pada medium Lowstein Jensen akan tumbuh dalam waktu 2-8 minggu dengan ciri-ciri koloni kuning pucat, permukaan kering dan pertumbuhan merata pada medium serta tidak larut apabila di suspensikan dengan air. Bakteri jenis Mycobacterium tuberculosis tumbuh pada suhu $25-40^{\circ} \mathrm{C}$, namun akan lebih tumbuh subur pada suhu $37^{\circ} \mathrm{C}$. Mycobactrium tuberculosis merupakan bakteri aerob, yang membutuhkan oksigen $\left(\mathrm{O}^{2}\right)$ untuk proses metabolismenya. $^{9}$

Hasil penelitian menunjukan sebagian kecil dari responden teridentifikasi kuman mycobacterium tuberculosis dalam sputum pada pekerja tambang emas tradisional. Pekerja tambang dalam aktivitasnya seringkali menghirup debu pertambangan dengan kondisi lingkungan pertambangan kotor sehingga pekerja tambang memiliki resiko mengalami gangguan fungsi paru yang membuat daya tahan tubuh pekerja tambang menjadi lemah. Keadaan tersebut mendukung masuknya bakteri Mycobacterium tuberculosis kedalam paru-paru.

Hasil penelitian menunjukkan bahwa kuman Mycobacterium tuberculosis dapat bertahan hidup pada tempat yang lembab, 
gelap, dan kuman Mycobacterium tuberculosis akan mati bila terkena sinar matahari. Kondisi pekerja tambang yang berhimpit-himpitan di dalam lubang pertambangan tanpa ventilasi membuat cahaya matahari tidak dapat masuk kedalam lubang pertambangan sehingga berisiko untuk terinfeksi kuman Mycobacterium tuberculosis. ${ }^{10,11,12}$

\section{Pendidikan}

Berdasarkan hasil penelitian diketahui dari 270 responden, $99(36,7 \%)$ responden berpendidikan SMP/MTsN dan $19(5,9 \%)$ responden tidak sekolah. Pekerja tambang emas tradisional rata-rata memiliki pendidikan rendah, jarang ditemukan menyelesaikan pendidikan sampai ke perguruan tinggi. Pendidikan dapat meningkatkan kematangan intelektual seseorang. Kemampuan intelektual ini berpengaruh pada wawasan, cara berfikir, cara pengambilan keputusan. Tingkat pendidikan seseorang akan mempengaruhi pengetahuan seseorang diantaranya mengenai penularan kuman mycobacterium tuberculosis, rumah yang memenuhi syarat kesehatan dan pencegahan penyakit TB Paru. Pendidikan yang rendah tercermin dalam hal menjaga kesehatan dan kebersihan lingkungan yaitu perilaku membuang dahak dan meludah di sembarang tempat. ${ }^{13}$

Pendidikan memiliki hubungan yang erat dengan kejadian TB Paru, hal ini dapat terjadi karena dengan pendidikan yang rendah maka kemampuan dalam menerima informasi semakin sulit, keinginan untuk mencari informasi juga jauh lebih rendah daripada orang dengan tingkat pendidikan yang lebih tinggi, selain itu orang dengan tingkat pendidikan rendah tidak memahami bagaimana menciptakan lingkungan yang mendukung untuk mencegah terjadinya penyakit menular seperti TB Paru. Seorang dengan tingkat pendidikan yang lebih tinggi lebih mampu untuk mengambil keputusan untuk menyelesaikan masalah kesehatan yang tengah terjadi dalam keluarganya, berbeda dengan orang yang memiliki tingkat pendidikan rendah yang masih berfikir dua kali atau meminta pendapat kepada anggota keluarga yang lain yang lebih tahu untuk menentukan tindakan apa yang akan dilakukan. ${ }^{14}$

Pendidikan yang rendah

mengakibatkan kesadaran untuk melakukan pencegahan TB Paru kurang dalam hal menjaga kesehatan, kebersihan lingkungan, membuang dahak dan meludah di sembarang tempat. ${ }^{4}$

\section{Umur}

Berdasarkan hasil penelitian diketahui dari 270 responden, $176(65,2 \%)$ responden memiliki umur 15-50 tahun. Rata-rata responden berumur 43,2 tahun, dimana responden paling mudah berumur 18 tahun dan paling tua berumur 67 tahun.

Pekerja tambang emas tradisional dilakukan pada usia dewasa, untuk usia remaja jarang ditemukan melakukan kegiatan pertambangan emas dikarenakan kegiatan ini memerlukan aktivitas fisik yang berat. Umur produktif yaitu 15-50 tahun paling sering ditemukan penderita TB Paru. ${ }^{15}$

Kekuatan untuk melawan infeksi adalah tergantung dari pertahanan tubuh seseorang dan sangat berpengaruh oleh umur penderita. Awal kelahiran seseorang sangat lemah akan meningkatkan sampai dengan usia 10 tahun dan kondisi terbaik setelah masa pubertas sampai habisnya masa produktif yaitu usia 45 tahun. ${ }^{16}$

Hasil penelitian menunjukkan bahwa responden yang teridentifikasi kuman mycobacterium tuberculosis $15,9 \%$ terjadi pada umur $15-50$ tahun dan 22, 3\% terjadi pada umur di atas 50 tahun. Penemuan sampel positif Tuberculosis Paru banyak terdapat pada umur dia tas 50 tahun, ini berhubungan dengan kondisi imunitas seseorang, pada usia lanjut seseorang akan mengalami penurunan kemampuan antibodi, disebabkan menurunnya fungsi kelenjar thymus yang merupakan penghasil sel $\mathrm{T}$ yang berperan dalam proses masuknya infeksi didalam tubuh, penurunan aktifitas sel $\mathrm{T}$ ini 
dipengaruhi oleh umur yang semakin tua sehingga sel $\mathrm{T}$ akan menjadi mengkerut. Akibatnya tubuh akan mengalami penurunan dalam melawan infeksi bakteri patogen yang masuk, salah satunya bakteri Mycobacterium tuberculosis. $^{17}$

Beberapa penelitian menunjukkan kecenderungan penderita TB Paru terdapat pada kelompok umur produktif antara 1555 tahun. Hasil penelitian menunjukkan hampir sebagian besar kasus TB Paru di Indonesia menyerang usia produktif atau kelompok usia kerja. Kekuatan untuk melawan infeksi tergantung pertahanan tubuh dan sangat dipengaruhi oleh umur penderita. Tingkat umur penderita dapat mempengaruhi kerja efek obat, karena metabolism obat dan fungsi organ tubuh kurang efisien pada orang tua sehingga dapat menimbulkan efk yang lebih kuat. ${ }^{18}$

\section{Kesimpulan}

Sebagian kecil dari responden yaitu $18,1 \%$ teridentifikasi kuman mycobacterium tuberculosis dalam sputum pada pekerja tambang emas tradisional di Lebong Tambang. Kegiatan pengeboran batu tambang yang dilakukan di lubang bawah tanah dengan kondisi yang lembab, kurang mendapatkan pencahayaan, sirkulasi udara yang buruk, dan terpapar dengan partikel debu yang mengandung kuman mycobacterium tuberculosis. Diharapkan kepada instansi kesehatan melaksanakan deteksi dini TB Paru pada pekerja tambang emas tradisional secara rutin, selain itu melaksanakan upaya preventif, promotif, dan kuratif untuk eliminasi TB Paru.

\section{Daftar Pustaka}

1. Rab T. Ilmu Penyakit Paru. Edisi ke Dua. Jakarta: Trans Info Media; 2013.

2. Chin J. Manual Pemberatasan Penyakit Menular. Edisi ke 17. Jakarta: Infomedika; 2014.
3. WHO. Global Tuberculosis Report. World Health Organization; 2017.

4. Kemenkes. Tuberkulosis Temukan Obati Sampai Sembuh. Jakarta: Pusat Data dan Informasi Kementerian Kesehatan RI; 2017.

5. Dinkes. Profil Dinas Kesehatan Provinsi Bengkulu; 2015.

6. Thomas C. Epidemiologi Suatu Pengantar. Jakarta: Buku Kedokteran EGC; 2012.

7. Asrina C., Rafael D., Muhammad R. Faktor yang Berhubungan dengan Kejadian Gangguan Fungsi Paru pada Pekerja Tambang Batu Bara PT. Indominco Mandiri Kalimantan Timur. Fakultas Kesehatan Masyarakat Universitas Hasanudin; 2012.

8. Perkumpulan Pemberatasan Tuberkulosis Indonesia (PPTI). Hubungan Rokok dan TBC. Jakarta; 2012.

9. Purwaningsih. Panduan pemeriksaan Sputum, Pada Laboratorium Mikrobiologi Kesehatan, Bandung; 2004.

10. Atmosukarto dan Srisoesanti. Pengaruh Lingkungan Pemukiman dalam Penyebaran Tuberculosis, Media Litbang Departemen Kesehatan Masyarakat, Vol 9 (4). 2000.

11. Aditama. Pemeriksaan Interferongamma dalam Darah untuk Deteksi Infeksi Tuberculosis.J. Tuberculosis Indonesia. Vol 3, (2). 2006.

12. Sholihah, Khariyati dan Setianingsih. Pajanan Debu Batu Bara dan Gangguan Pernapasan pada Pekerja Lapangan Tambang Batu Bara, J. Kesehatan Masyarakat. Vol 4, (2). 2008.

13. Suarni H. Faktor Risiko yang Berhubungan dengan Kejadian Penderita Penyakit TB Paru BTA Positif di Kecamatan Pancoran Mas Kota Depok. Fakultas Kesehatan Masyarakat Universitas Indonesia: 2009.

14. Ristyo S., Imam A., dan Pepin N. Hubungan Tingkat Sosial Ekonomi dengan Angka Kejadian TB Paru BTA Positif di Wilayah Kerja Puskesmas Peterongan Jombang. Program Keperawatan STIKES Pemkab Jombang; 2012.

15. Naga S. Ilmu Penyakit Dalam. Yogyakarta: Diva Press; 2012.

16. Tanjung A., Keliat E. Resistensi Mycobacterium Tuberculosis terhadap Obat Anti Tuberkulosis Paru yang Telah Mendapatkan Pengobatan. Majalah Kedokteran Indonesia: Vol.54 (5). 1996.

17. Ria M. Deteksi Suspek Tuberculosis paru pada Pekerja Tambang Emas Pobiyi Palu Sulawesi Tengah. Universitas Tadulako. 2013.

18. Kemenkes RI. Pedoman Nasional Pengendalian Tuberkulosis: Indonesia Bebas Tuberkulosis. Jakarta: Departemen Kesehatan RI; 2017. 